\title{
Antimicrobial performance of cotton finished with triclosan, silver and chitosan
}

\author{
Guneet Dhiman and J. N. Chakraborty * (1)
}

*Correspondence:

chakrabortyjn@hotmail.com National Institute

of Technology, Jalandhar 144 011, India

\begin{abstract}
Antimicrobial agents are applied on textiles to suppress growth of microorganism, odour generation as well as its deterioration. Cotton fabric was finished with three different types of antimicrobial agents (1) Ultrafresh NMV2: a triclosan based product, (2) N9 Pure silver: a dispersion of pure silver metal, and (3) chitosan to develop antimicrobial characteristics. Finished fabrics were evaluated for their effectiveness against Gram positive bacterium (Staphylococcus aureus) and Gram negative bacterium (Escherichia coli) in terms of percentage reduction in CFU of bacteria. The influence of finishing methods, via. pad-dry and pad-dry-cure followed by repeated launderings, concentrations of antibacterial agents, and pH were optimised. The antimicrobial performance was evaluated prior to laundering and after each five laundering cycles; results were statistically analysed and effects on physical properties of the finished fabric were also evaluated. Triclosan was found to be significantly effective at low concentrations, whereas silver showed remarkably good antimicrobial activity at or above $10 \mathrm{~g} / \mathrm{L}$ and chitosan was comparably less active compared to others. Cyclic laundering showed statistically significant effect on activity of finishes up to five cycles but it was almost reduced to half for chitosan.
\end{abstract}

Keywords: Antimicrobial, Triclosan, Silver, Chitosan, E. coli, S. aureus

\section{Introduction}

Textiles act as the carriers for microorganisms, such as pathogenic and odour generating bacteria, mould and fungi causing damage to clothing, strength loss, staining, discoloration and may even cause skin diseases. Antimicrobial finishes maintain hygiene and enables to avoid infection from pathogens especially in hospitals, nursing homes, schools, hotels, and crowded public areas. They prevent unpleasant odour on intimate apparel, underwear, socks and athletic wear. Microbes attack natural fibres because they are hydrophilic in nature. In cotton under certain conditions the presence of carbohydrates acts as nutrients and energy source to microbes. Various other sources of nutrients for microorganisms are soil, dust, solutes from sweat and some textile finishes (Gao and Cranston 2008; Schindler and Hauser 2004; Srivastava 2011). Antimicrobial agents are of two types: leaching and non-leaching. Leaching types work through controlled release mechanism by leaching on the fabric surface or at the interior of the fibre. These are effective against microbes on the fibre surface or in the surrounding environment and include triclosan (2,4,4'-trichloro-2'-hydroxydiphenyl ether), copper naphthenate, 
quaternary ammonium salts, benzimidazol derivatives etc. Non-leaching types bind to the fibre surfaces and control those microbes that come in contact with the fibre surface only. This type includes chitosan, octadecyl aminodimethyl trimethoxy silylpropyl ammonium chloride, poly-hexamethyl biguanide etc. Antimicrobial finishes can be applied on textile substrates by exhaust, pad-dry-cure, coating, spray methods or in spinning dope (Dorugade and Bhagyashri 2010; Elshafei and El-Zanfaly 2011; Mao 2002; Ristić et al. 2011; Shrivastava et al. 2011; Technical Bulletin 2004). Antimicrobial agents control the growth of microbes by various mechanisms ranging from preventing cell reproduction, blocking of enzymes, reaction with the cell membrane to the destruction of the cell walls and poisoning the cell from within (Schindler and Hauser 2004). Various requirements of these finishes in textiles are durability to washing, dry cleaning and hot pressing, no harmful effects to the user and the environment, compliance with the statutory requirements of regulating agencies, compatible with the chemical processes and easy application without deteriorating fabric quality (Schindler and Hauser 2004; Thiry 2010).

Triclosan (2,4,4'-trichloro-2'-hydroxydiphenyl ether) is effective against most of the bacteria and has poor antifungal properties. It is lipophilic in nature and practically insoluble in water $(0.004 \%)$. It is soluble in various chemicals and solvents such as ethanol, diethyl ether, in stronger basic solutions such as $1 \mathrm{M}$ sodium hydroxide etc. (Mehmet 2012). Pure triclosan powder has poor solubility in water and is not possible to apply on the fabric by pad-dry method. Its aqueous application requires use of dispersing agents and binders (Annis 2012; Gao and Cranston 2008; Schindler and Hauser 2004). In order to make triclosan soluble methanol was found to be a good solvent but had other problems like increase in cost and possibilities of interfering with other finishes.

Triclosan works specifically by inhibiting the active site of the enoyl-acyl carrier protein reductase enzyme (ENR) which is an essential enzyme in fatty acid synthesis required for building cell membranes and lipid production in the microbe by blocking the synthesis of lipids (Annis 2012; Dorugade and Bhagyashri 2010; Gao and Cranston 2008; Purvar and Joshi 2004). It also uses an electro chemical mode of action to penetrate and disrupt the cell walls of microorganisms that causes metabolites leakage and disabling other cell functions, thereby preventing the organism from functioning or reproducing. On textiles it inhibits the growth of microbes in contact with the surface using barrier or blocking action (Mansfield 2002; Ramachandran and Rajendran 2004).

Ultrafresh NMV2, a bacteriostatic product from Thomson Research Associates with EPA Reg. No. 10466-27 was selected containing $3 \%$ of 5-chloro-2-(2,4-dichlorophenoxy) phenol i.e. triclosan as its active ingredient along with $97 \%$ undisclosed ingredients in it. It is an aqueous emulsion (dispersed in aqueous media) designed for its application to textiles in order to provide durable bacteriostatic properties by inhibiting the growth of odour caused by bacteria on textile surface (Technical data sheet 2000).

Silver has low toxicity to humans and is effective against a broad spectrum of microorganism along with its high efficiency and 'oligodynamic' nature (Emam et al. 2013; Montazer et al. 2012). Biocidal silver is suitable for a wide range of industrial applications and research in its various forms such as metallic, salts, oxidation states $\left(\mathrm{Ag}^{0}, \mathrm{Ag}^{+}, \mathrm{Ag}^{2+}\right.$, and $\mathrm{Ag}^{3+}$ ) and nano particles act as sources of silver ions (Budama et al. 2013; Dubas et al. 2006; Matyjas-Zgondek et al. 2008). 
There are various proposed mechanisms for silver for its antibacterial activity like release of silver ion which pass through cell membrane of bacteria causing structural changes in cell walls by binding to negatively charged components in proteins and nucleic acids leading to its proteins inactivation and interference with DNA replication. Silver ions are thought to interact with thiol $(-\mathrm{SH})$ groups, carboxylates, phosphates, hydroxyls, imidazoles, indoles and amines either singly or in combination causing multiple deleterious events that interferes with microbial processes. It decreases the enzymatic activity of cell that changes the microorganism metabolism which ultimately leads to microbial cell death. It also catalyzes the production of active species such as oxygen radicals which results in oxidation of the molecular structure of bacteria (Budama et al. 2013; Dubas et al. 2006; Emam et al. 2013; Mahapatra 2013; Montazer et al. 2012; Purvar and Joshi 2004; Ristić et al. 2011; Windler et al. 2013).

N9 Pure Silver is a micro suspension possessing dark blue colour with CAS. No 744022-4 with its active compound as $0.5 \%$. It is pure metallic silver in ultra-pure de-ionized water and is highly effective to deactivate bacterial attack and other microbes with low silver loading. It doesn't leach out, remains intact on the treated surface and acts when need arises to protect the textile against microbes (Technical data sheet 2013).

Chitosan is a linear polycationic polysaccharide composed of randomly distributed $\beta$-(1-4)-linked d-glucosamine (deacetylated unit) and $\mathrm{N}$-acetyl-D-glucosamine (acetylated unit) and has numerous features like biodegradability, non-toxicity, non-allergic, cationic nature, and antimicrobial. Its activity depends on its molecular weight (at least 10,000 for adequate antimicrobial efficacy), degree of deacetylation and $\mathrm{pH}$. It is soluble only in certain dilute acid solutions and increase in degree of deacetylation improves its solubility in acidic $\mathrm{pH}$ by creating more amino groups. Its affinity on cotton would be due to Van der Waal's forces and H-bonding due to similar structure as of cellulose (Annis 2012; Bashar and Khan 2013; Gao and Cranston 2008; Huang et al. 2008; Raafat et al. 2008).

Chitosan has various proposed mechanisms for its antimicrobial activity like (1) formation of a polymer membrane of chitosan on the surface of the cell preventing nutrients from entering the cell, (2) lower molecular weight chitosan enters the cell and binds to DNA and inhibiting RNA and protein synthesis, (3) chitosan disturbs the physiological activities of the microorganism leading to death of the cells as it can adsorb the electronegative substance in the cell and flocculate them, (4) chitosan's polycationic nature can bind predominantly with the anionic components (lipopoly-saccharides and proteins of microorganism surface)/anionic sites in proteins, which results in changes in permeability, inducing leakage of intracellular components causing death of the cell (Eltahlawy et al. 2005; Purvar and Joshi 2004).

This present study was aimed at investigating the most effective and durable antimicrobial activity on cotton fabric for three different types of antimicrobial agents, i.e. (1) triclosan based (Ultra fresh NWV2), (2) silver (N9 Pure micro silver) and (3) chitosan in pad-dry and pad-dry cure techniques. Quantitative assessment of antimicrobial performances were made by calculating \% reduction in colony forming units (CFU) of bacteria against two challenged microorganisms (1) Staphylococcus aureus (S. aureus), a Gram positive bacterium and (2) Escherichia coli (E. coli), a Gram negative bacterium. Laundering durability of finishes on cotton fabrics was investigated for five cycles. Obtained 
results were statistically analyzed using ANOVA at $95 \%$ confidence level and physical properties of finished cotton were also evaluated.

\section{Methods}

Material

Bleached and mercerized plain woven cotton fabric possessing $0.126 \mathrm{~kg} / \mathrm{m}^{2}, 55$ ends per $\mathrm{cm}, 28$ picks per $\mathrm{cm}, 67.6 \mathrm{Nm}$ warp (40 s warp) and $67.6 \mathrm{Nm}$ weft (40 s weft) count was used. Triclosan based Ultrafresh NMV2 and Silver based N9 Pure Silver Micro were procured from Resil Chemicals (Bangalore, India) and chitosan (>75 \% deacetylation) was procured from Hi Media (Mumbai, India). Gram positive bacteria S. aureus ATCC 6538 and Gram negative bacteria E. coli ATCC 10536 were two studied microorganisms and supplied by Imptech, Chandigarh.

\section{Efficiency of antimicrobial agents}

For triclosan and silver based antimicrobial agents a general efficiency test through agar was carried out with "Zone of inhibition" method. On separate nutrient agar plates $100 \mu \mathrm{l}$ of $S$. aureus (enumeration of bacterial inoculum $5.0 \times 10^{8} \mathrm{CFU} / \mathrm{ml}$ ) and E. coli (enumeration of bacterial inoculum $2 \times 10^{8} \mathrm{CFU} / \mathrm{ml}$ ) was spread with spreader. On each plate a small pocket was made and $100 \mu \mathrm{l}$ of pure antimicrobial agents were placed in it. Plates were kept in incubator for $24 \mathrm{~h}$ to determine inhibition zones for both agents.

\section{Application of antimicrobial agents}

Aqueous solutions of the antimicrobial agents were prepared at specific $\mathrm{pH}$ with constant stirring. Cotton fabrics were treated separately by immersing in antimicrobial finishing liquors for $30 \mathrm{~s}$ for Ultrafresh NMV2 (triclosan) as well as for N9 Pure silver (silver) agents and $10 \mathrm{~min}$ for chitosan (as pad liquor was too viscous and was not exhausted with ease on cotton) followed by padding on laboratory padder under controlled pressure and speed to achieve 70-80 \% expression (owf). Fabrics were dried at $80{ }^{\circ} \mathrm{C}$ for $5 \mathrm{~min}$. Curing was done at $150{ }^{\circ} \mathrm{C}$ for $5 \mathrm{~min}$. Table 1 mentions the various concentrations of antimicrobial agents studied.

\section{Evaluation of properties of finished cotton}

Antimicrobial activity for both untreated and treated cottons was evaluated against two selected microorganisms i.e. S. aureus a Gram positive bacterium and E. coli a Gram negative bacterium by evaluating its percentage reduction rates (\% R) in its bacteria's CFU by using AATCC test method 100:2004. Laundering tests on finished fabrics were carried out using $5 \mathrm{~g} / \mathrm{L}$ laundry soap solution along with $2 \mathrm{~g} / \mathrm{L} \mathrm{Na}_{2} \mathrm{CO}_{3}$, bath ratio of 1:50

Table 1 Concentrations of antimicrobial agents

\begin{tabular}{lll}
\hline S. no. & Antimicrobial agent & Concentration $\mathbf{( g / L )}$ \\
\hline 1 & Triclosan & $5,10,20,30,40,50,60$ \\
2 & Silver & $3,5,10,20,30,40$ \\
3 & Chitosan & $3,5,10,15,20$ \\
\hline
\end{tabular}


at $35-37^{\circ} \mathrm{C}$ for $30 \mathrm{~min}$ in laundero-meter. Physical properties of finished fabrics were evaluated for total crease recovery (TCRA, AATCC Test 66-2003), tensile strength (ISO 13934-1:1999), tearing strength (ASTM D1424-09), bending length (ASTM D1388), air permeability (AP, BS 5636) and for assessment of whiteness index, spectrophotometer (Datacolor Check, USA) was used at $400 \mathrm{~nm}$ wavelength.

\section{Statistical analysis}

The antimicrobial activity and durability to laundering cycles of antimicrobial finished cotton fabrics were statistically analyzed using ANOVA at $95 \%$ confidence level using Statistica 10. The independent factors were antimicrobial agent concentration, laundry cycles, and bacteria in order to study any statistically significant differences between treatments on finished cotton.

\section{Experimental plan}

Finishes were applied on cotton initially at specific concentration using (a) pad-dry and (b) pad-dry-cure to develop antibacterial activity that would be more durable for antimicrobial performance. AATCC test method 100:2004 was used for quantitative evaluation for finished fabrics with and without repeated laundering upto five cycles. The initial concentrations selected for triclosan and silver were 60 and $10 \mathrm{~g} / \mathrm{L}$ respectively at $\mathrm{pH}$ 6. Chitosan (5 g/L) was dissolved in $1 \%$ acetic acid for its deionization and complete solubility. Based on these results, application method was selected accordingly for each agent that showed highest levels of antimicrobial performance at optimum concentrations. The effect of $\mathrm{pH}$ on antimicrobial activity was also studied. Finish durability of each agent for its optimum concentrations was evaluated. Physical properties of finished cotton as well as antimicrobial performance up to five laundering cycles were evaluated.

\section{Anti-microbial testing}

Anti-microbial testing was done by AATCC test method 100:2004 for the quantitative assessment of the antibacterial effectiveness of the antimicrobial agents against Gram positive bacteria (Staphylococcus aureus) and Gram negative bacteria (Escherichia coli). Circular swatches of $4.8 \pm 0.1 \mathrm{~cm}$ in diameter were cut from the test fabric. The cut pieces were stacked in $250 \mathrm{ml}$ wide mouth glass jar with a screw cap followed by sterilization at $121^{\circ} \mathrm{C}$ for $15 \mathrm{~min} .0 .5 \mathrm{ml}$ of the bacterial solution was added to the swatches so that whole of it is absorbed by one swatch. The jar was kept for $24 \mathrm{~h}$ in the incubator at $37^{\circ} \mathrm{C}$. After $24 \mathrm{~h} 50 \mathrm{ml}$ of sterilized saline water was added to each jar followed by 15 min shaking in the shaker. Further three serial dilutions were done by taking $100 \mu \mathrm{l}$ in $900 \mu \mathrm{l}$ of saline water in eppendorf micro test tubes. Nutrient agar plates were made and $100 \mu \mathrm{l}$ of this diluted bacterial solution was inoculated into the agar plate and left for $24 \mathrm{~h}$ in incubator at $37^{\circ} \mathrm{C}$. After $24 \mathrm{~h}$ the number of bacterial CFU of the bacteria formed on the agar plate were counted. Untreated cotton sample was used as the control sample every time.

Percentage reduction ( $\mathrm{R} \%$ ) of bacterial growth i.e. CFU on treated samples was calculated in comparison with untreated fabric according to following relationship:

$$
\mathrm{R}(\%)=\frac{(\mathrm{U}-\mathrm{T})}{\mathrm{U}} \times 100
$$


where $\mathrm{U}$ is the number of bacteria CFU recovered from the inoculated untreated cotton test specimen swatches in the jar incubated over the desired contact period and $\mathrm{T}$ is the number of bacteria CFU recovered from the inoculated treated test specimen swatches in the jar incubated over the desired contact period.

\section{Results and discussion}

Triclosan and silver ions leach out or move away from the applied surface and work on leaching mechanism at a slow yet sustained controlled rate to provide protection against microbes (Kut et al. 2005). Triclosan is a non-ionic agent, therefore, it is assumed that it doesn't form chemical bonds with cellulose. It has low molecular weight and acts like a disperse dye with high exhaustion rate that diffuses into the fibre like polyester and nylon (Gao and Cranston 2008).

Silver particles are incorporated in synthetic polymers before extrusion and during its use it diffuses onto the surface of the fibre where it forms silver ions in the presence of moisture and acts against microbes. Release rate of silver from the fibre can be influenced by the physical and chemical characteristics of the fibre as well as the amount of silver in the fibre (Gao and Cranston 2008). N9 Pure silver is in nonionised metallic state. It doesn't leach out from the fabric and acts against the microbes through contact with surface.

Triclosan and silver agents were evaluated for "Zone of inhibition" test which provided qualitative analysis of the extent to which antimicrobial agents effectively migrated onto the agar and diffused outward. Figure 1 represents the zone of inhibition for E. coli bacterium with both triclosan and silver based antimicrobial agents marked as C1 and C2 respectively. The same was done using $S$. aureus bacterium and results were same as for E. coli. It was found that Triclosan leached out to great extent and had more zone of inhibition whereas silver had a very low zone of inhibition due to inability of functional silver to diffuse through nutrient agar because it binds with proteins in the agar (Swofford 2010). This test wasn't done for chitosan as it forms bonds with cellulose and remains incapable to leach out.

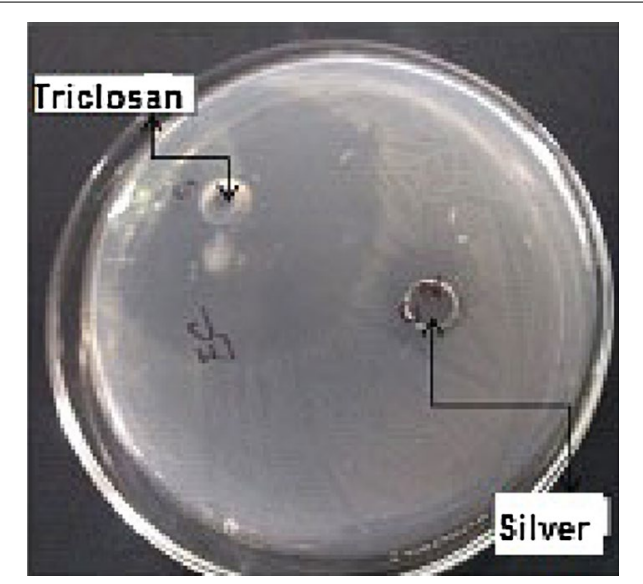

Fig. 1 Representing the "Zone of inhibition" for triclosan and silver based antimicrobial agents against E. coli (C1 triclosan based and C2 silver based antimicrobial agents) 


\section{Evaluation of antibacterial activity in various padding methods}

The finished cotton fabrics were evaluated for antimicrobial activity against S. aureus and $E$. coli before and after each laundering cycle up to five times. The results for all three agents with two different application methods are presented in Table 2. It was found that for triclosan and silver based finishes no substantial differences were noticed in antibacterial activity against both selected bacteria after curing. No significant difference was found among both application methods for triclosan and silver whereas the results for chitosan showed better activity after curing. There was $100 \%$ reduction in antimicrobial activity in both the methods with triclosan $(60 \mathrm{~g} / \mathrm{L})$ against both bacteria without laundering. It retained its antimicrobial activity up to $99.98 \%$ even after 5 th laundering cycle. For further study, the concentration of triclosan was formulated from $5 \mathrm{~g} / \mathrm{L}$ onwards. Silver at $10 \mathrm{~g} / \mathrm{L}$ showed comparatively same reduction rates for both application methods against both bacteria. It showed 95.65 and $92.5 \%$ reduction rates without any laundering and after five laundering showed 94.44 and $91.14 \%$ reduction rates for S. aureus and E. coli respectively. N9 pure silver based agent had only silver particles dispersed in water and it required no curing as it does not possess crosslinking groups; concentration of it was selected from $3 \mathrm{~g} / \mathrm{L}$ onwards.

Both triclosan and silver are applied on the surface of the cotton fabric. Due to their low molecular weight they can leach out. For N9 pure silver it remains intact on the fibre surface, but it also leaches out as can be seen from Fig. 1 on testing its efficiency against microbes on agar plate. Chances are that these agents remain coated on the surface as well as get trapped inside the cellulose convolutions due to application of force during padding and act until their reservoir ends with usage and repeated launderings.

From Table 2 the launderability results for pad-dry and pad-dry cure methods for all three agents against both microbes showed that curing was not required for triclosan and N9 pure silver to bind these on cellulose as no such difference in the antimicrobial

Table 2 Evaluation of antibacterial activity of finished cotton in various padding methods

\begin{tabular}{|c|c|c|c|c|c|c|c|c|}
\hline \multirow[t]{3}{*}{ Antimicrobial agent } & \multirow[t]{3}{*}{ Application method } & \multirow[t]{3}{*}{ Bacteria } & \multicolumn{6}{|c|}{ \% Reduction in CFU of bacteria } \\
\hline & & & \multicolumn{6}{|c|}{ Laundry cycle } \\
\hline & & & 0 & 1 & 2 & 3 & 4 & 5 \\
\hline UN & - & E. coli & NR & NR & NR & NR & NR & NR \\
\hline UN & - & S. aureus & NR & $N R$ & NR & NR & NR & NR \\
\hline \multirow[t]{4}{*}{ Triclosan (60 g/L) } & Pad-dry & E. coli & 100 & 100 & 100 & 100 & 99.99 & 99.98 \\
\hline & Pad dry cure & E. coli & 100 & 100 & 100 & 100 & 99.99 & 99.98 \\
\hline & Pad-dry & S. aureus & 100 & 100 & 100 & 100 & 99.99 & 99.98 \\
\hline & Pad dry cure & S. aureus & 100 & 100 & 100 & 100 & 99.99 & 99.98 \\
\hline \multirow[t]{4}{*}{ Silver (10 g/L) } & Pad-dry & E. coli & 92.5 & 92.3 & 91.84 & 91.67 & 91.34 & 91.13 \\
\hline & Pad dry cure & E. coli & 92.5 & 92.1 & 91.89 & 91.63 & 91.34 & 91.14 \\
\hline & Pad-dry & S. aureus & 95.65 & 95.39 & 95.21 & 94.92 & 94.73 & 94.48 \\
\hline & Pad dry cure & S. aureus & 95.67 & 95.34 & 95.2 & 94.95 & 94.71 & 94.44 \\
\hline \multirow[t]{4}{*}{ Chitosan (5 g/L) } & Pad-dry & E. coli & 63.01 & 37.74 & 33.89 & 27.13 & 20.49 & 14.31 \\
\hline & Pad dry cure & E. coli & 69.23 & 51.39 & 47.92 & 43.85 & 35.53 & 29.96 \\
\hline & Pad-dry & S. aureus & 72.24 & 43.98 & 40.67 & 34.81 & 28.94 & 21.83 \\
\hline & Pad dry cure & S. aureus & 81.37 & 68.38 & 64.59 & 57.6 & 52.07 & 48.97 \\
\hline
\end{tabular}

UN unfinished cotton, $N R$ no reduction in CFU of bacteria 
activity was found for both the padding techniques up to their 5th laundering cycles. Therefore, it could be concluded that curing doesn't show any influence on fixation as well as durability of triclosan and silver agents.

These finishes didn't require any specific application technique and could be easily applied by pad-dry method. Obviously, for further studying the effect of concentration, $\mathrm{pH}$ and launderability on antimicrobial activity, these were applied only by pad dry method.

Chitosan at $5 \mathrm{~g} / \mathrm{L}$ showed comparatively poor activity against both bacteria. Loss in antimicrobial activity was obtained after first laundry cycle to a great extent. The reduction rates were better i.e. $68.38 \%$ as compared to $43.98 \%$ for S. aureus and $51.39 \%$ as compared to $37.74 \%$ for $E$. coli with and without curing steps respectively. Up to 5 th laundry the activity was reduced to 48.97 and $29.9 \%$ for $S$. aureus and E. coli respectively even after curing. This could be due to removal of a superficial layer of chitosan from the fabric. Structure of chitosan resembles to that of cellulose and binds with cellulose through H-bonds and Van der Waal's forces; curing could have resulted in formation of more bonds with cellulosic structure. Hence, for further finishing of cotton with chitosan and to see its durability on antimicrobial activity pad-dry-cure method was applied with curing at $150{ }^{\circ} \mathrm{C}$ for $5 \mathrm{~min}$.

\section{Effect of concentration of antimicrobial agents on antimicrobial activity}

All the three antimicrobial agents were applied on cotton at different concentrations at $\mathrm{pH} 6$, and antimicrobial activity of finished cotton fabrics on percentage reduction in CFU against S. aureus and E. coli are shown in Figs. 2, 3, and 4 for triclosan, silver and chitosan respectively. It was observed that regardless of triclosan concentration, the finished cotton fabrics showed over $90 \%$ reduction in number of CFU against both $E$. coli and $S$. aureus, indicating excellent antimicrobial activity of triclosan at even low concentration of $5 \mathrm{~g} / \mathrm{L}$ (Fig. 2). Reduction increased up to $>99.99 \%$ with increase in its concentration at $20 \mathrm{~g} / \mathrm{L}$ and beyond that $100 \%$ reduction was obtained against both bacteria. This confirmed that triclosan was noticeably effective in reducing bacterial growth tremendously for both Gram positive and Gram negative bacteria even at

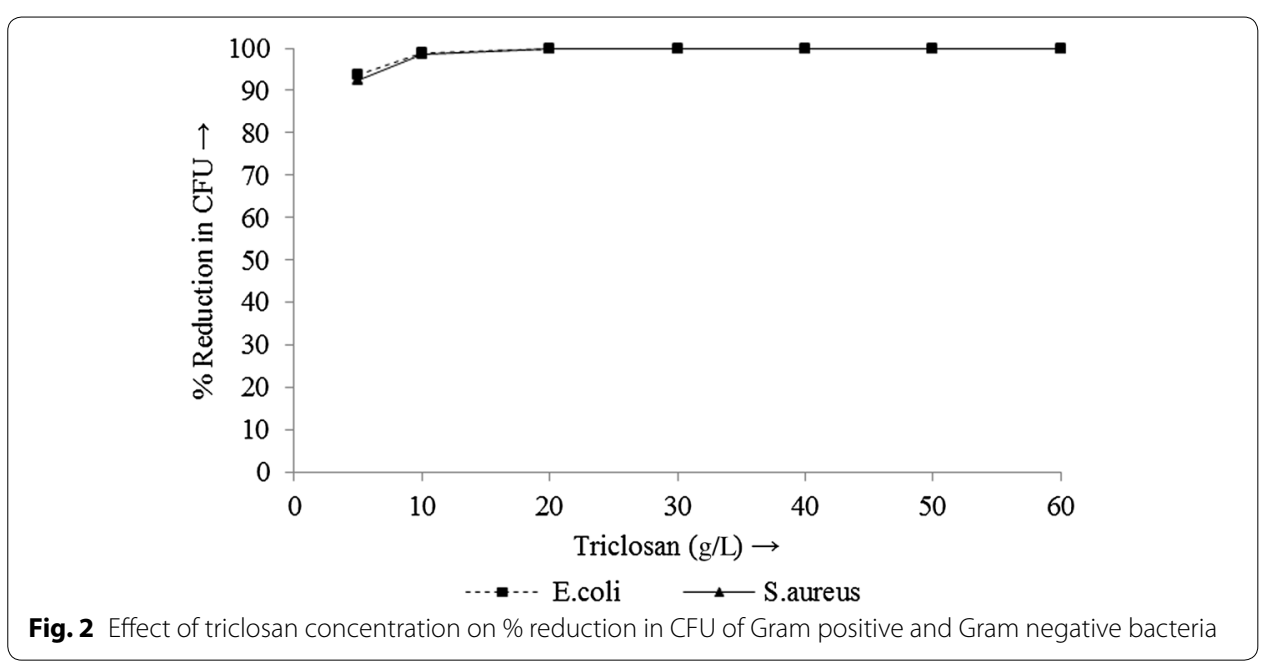


lower concentrations. Silver finished cotton fabrics (Fig. 3) also showed a reduction rate of $>90 \%$ against both E. coli and S. aureus bacteria at $10 \mathrm{~g} / \mathrm{L}$ and the reduction increased up to $99.99 \%$ with increase in concentration of silver at or beyond $30 \mathrm{~g} / \mathrm{L}$. Silver at lower concentrations did not show any remarkable reduction. At $5 \mathrm{~g} / \mathrm{L}$ concentration it showed only around 45.89 and $47.76 \%$ reductions in CFU for E. coli and S. aureus respectively. At $3 \mathrm{~g} / \mathrm{L}$ silver the antimicrobial activity was around $21 \%$ against both bacteria. Therefore, it was concluded that silver based antimicrobial finish required higher concentration i.e. at least $10 \mathrm{~g} / \mathrm{L}$ to show required antimicrobial activity.

The reduction rate of chitosan finished fabrics (Fig. 4) was somewhat lower than that with triclosan and silver finishes. It was observed that for chitosan it exhibited good antimicrobial activity when its concentration was increased from 3 to $10 \mathrm{~g} / \mathrm{L}$ and after that there was no remarkable improvement in its activity against both selected microorganisms. It showed antimicrobial activity above $90 \%$ for $S$. aureus and above $80 \%$ for $E$. coli at $10 \mathrm{~g} / \mathrm{L}$ respectively. At $20 \mathrm{~g} / \mathrm{L}$ the reduction rate increased up to 94.62 and $88.73 \%$ for S. aureus and for E. coli. With increase in concentration of chitosan, the viscosity of the bath also went on increasing posing difficulty on smooth application with proper penetration. That is why effectiveness of chitosan was studied up to $20 \mathrm{~g} / \mathrm{L}$. Another problem with chitosan was stiff handle of fabric with increased concentration. It may
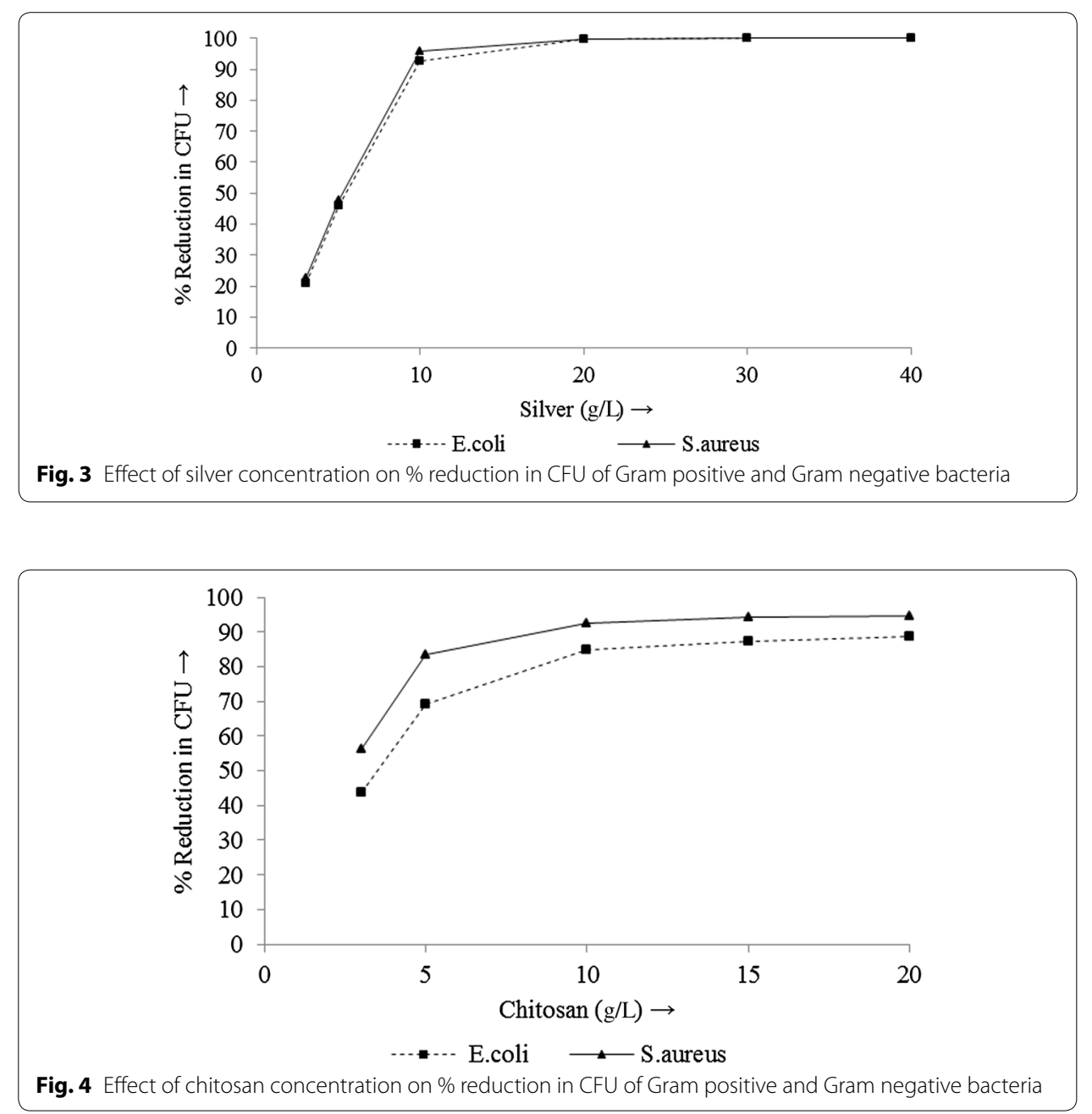
be concluded that both triclosan and silver based finishes showed markedly higher reduction rates and were easy to apply on cotton whereas chitosan was difficult to apply because of viscous bath and showed comparatively less activity. Chitosan produced stiff handle to the fabric. Almost $100 \%$ protection against both microorganisms was achieved with triclosan $(20$ and $30 \mathrm{~g} / \mathrm{L}$ ) and silver (30 and $40 \mathrm{~g} / \mathrm{L}$ ). Chitosan concentration at $15 \mathrm{~g} / \mathrm{L}$ was comparatively easier to apply and showed almost same activity as that at $20 \mathrm{~g} / \mathrm{L}$. These concentrations were further studied for evaluating effect of repeated laundering on durability of finish. Effect of $\mathrm{pH}$ was also studied for both triclosan and silver finishes at $30 \mathrm{~g} / \mathrm{L}$.

\section{Effect of $\mathrm{pH}$ on antimicrobial activity}

Effect of $\mathrm{pH}$ on antimicrobial performances against S. aureus and E. coli was studied with triclosan and silver at $30 \mathrm{~g} / \mathrm{L}$ each. The antimicrobial activity at 4, 5, $6 \mathrm{pH}$ for both these agents are presented in Fig. 5. It was observed that in case of triclosan, pH did not have any negative impact on its antimicrobial performance against both bacteria but silver based finish showed slight negative impact on its antimicrobial performances against both bacteria and fall in $\mathrm{pH}$ from 6 to 4, it got reduced from 99.99 to 91.87 and $92.33 \%$ for S. aureus and E. coli respectively. N9 pure metallic silver was used for finishing which in turn possibly show high tendency to get ionised due to reaction with acid with successive fall in $\mathrm{pH}$, i.e. increase in acidity of bath and was not exhausted on cotton rather showed affinity towards acid. Therefore, $\mathrm{pH} 6$ was accepted as the optimum for both agents. As chitosan dissolves at $\mathrm{pH}$ around 5-6 its performance against change in $\mathrm{pH}$ wasn't conducted.

\section{Laundering durability of antimicrobial finished cotton}

Cotton finished with triclosan (20 and $30 \mathrm{~g} / \mathrm{L}$ ), silver (30 and $40 \mathrm{~g} / \mathrm{L}$ ) and chitosan $(15 \mathrm{~g} / \mathrm{L})$ were evaluated to study durability of finish after repeated laundering. Figure 6 shows the changes in antimicrobial activity of finished cotton without laundering and after each laundering up to five cycles. The results for both triclosan and silver based

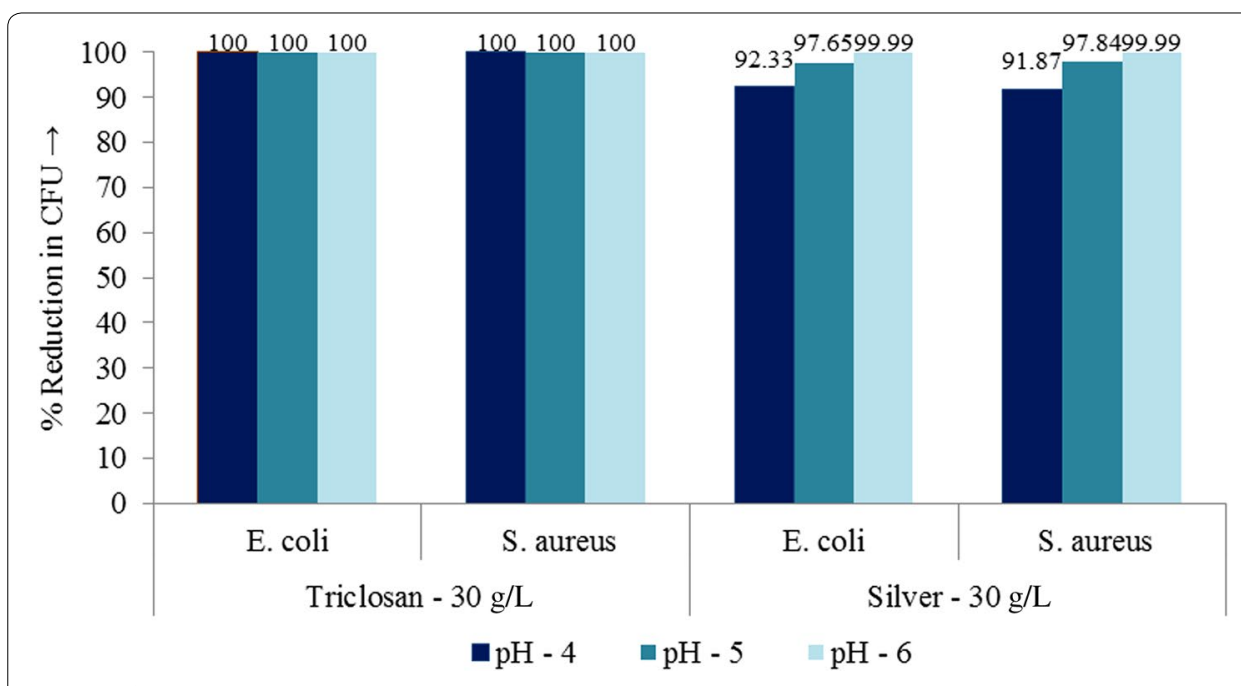

Fig. 5 Effect of pH on antimicrobial activity of triclosan and silver based antimicrobial agents on cotton fabric 
finishes were consistent and were found to be extremely effective against both $S$. aureus and E. coli bacteria. They exhibited slight decrease in their antimicrobial activities even after five repeated laundering cycles; whereas, chitosan finished laundered fabrics showed drastic decrease in antimicrobial activity probably because of removal of finish from fabric as chitosan forms weak binding with cellulose and loss of its cationic nature under alkaline conditions of laundering. In case of triclosan, finished cotton durability was maintained up to five laundering cycles and showed $>98$ and $>99 \%$ reduction rates for 20 and $30 \mathrm{~g} / \mathrm{L}$ finished fabrics respectively against $S$. aureus and E. coli, showing high antimicrobial effectiveness and durability properties. Similar was the case with silver as it maintained its antimicrobial properties $>99 \%$ reduction rates for 30 and $40 \mathrm{~g} / \mathrm{L}$ against S. aureus and E. coli respectively. From Table 2 it was found that at $10 \mathrm{~g} / \mathrm{L}$ silver finished cotton showed $>90$ and $>94 \%$ reduction in CFU of $E$. coli and $S$. aureus by 5 th laundry cycle. Chitosan $(15 \mathrm{~g} / \mathrm{L})$ finished cotton showed more than 87 and $94 \%$ reduction rate for $E$. coli and S. aureus respectively without any laundering. After first laundering there was significant loss in its antimicrobial activity. By the end of 5th laundry cycle there was substantial decrease in its activity to 46 and $55 \%$ respectively for E. coli and S. aureus.

It may be concluded that both triclosan and silver based finished cotton showed excellent antimicrobial activity above for both $98 \%$ against $E$. coli and $S$. aureus bacteria even after 5 th laundry cycle but for chitosan it was almost reduced to half. It is highly recommended to use binding agents for crosslinking chitosan with cellulose to obtain good durability results.

The launderability results for all three agents as shown in Fig. 6 were statistically analysed for each agent with ANOVA. In case of triclosan, concentration, laundry cycles and bacteria along with interaction effect of laundry cycle with concentration showed statistical significant difference $(\mathrm{p}<0.05)$ in \% reduction of CFU with their percentage contribution as $21.1 \%$ with concentration, $61.5 \%$ with laundry cycles and $17.3 \%$ due to interaction effect of concentrations of antimicrobial agent and laundry cycles. In case of silver, its concentration, bacteria and laundry cycle along with interaction of

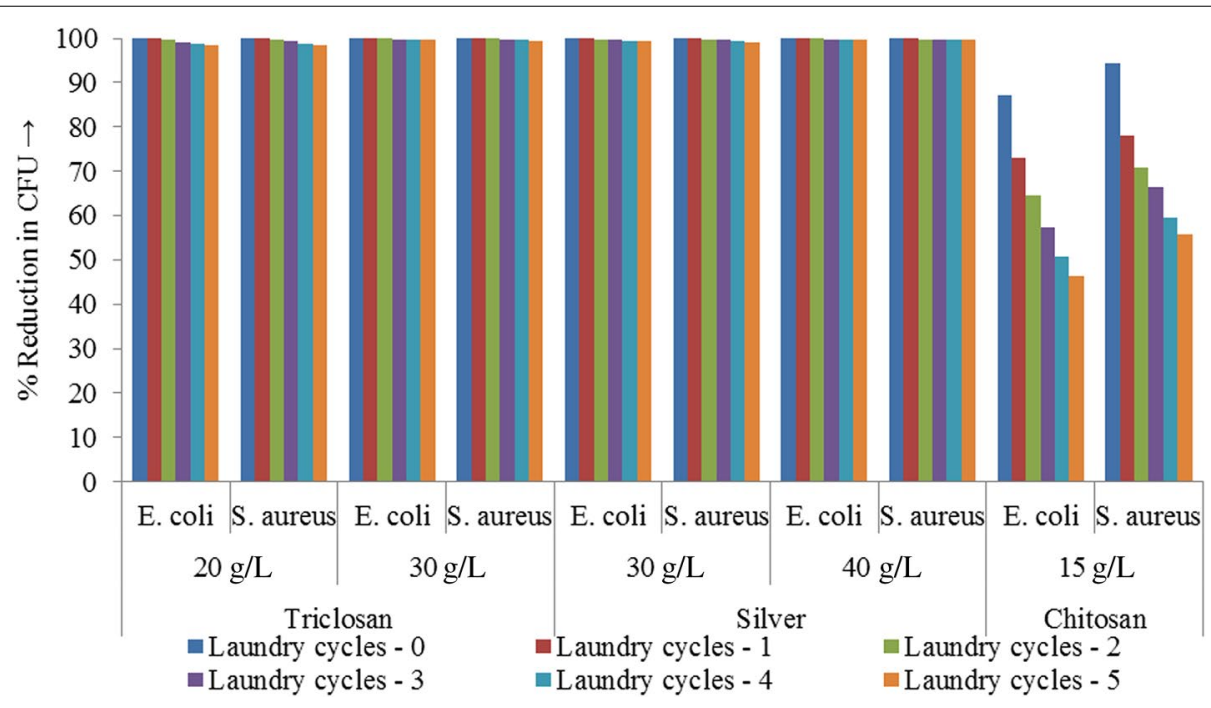

Fig. 6 Antimicrobial activity of antimicrobial finished cotton on repeated launderings 
concentration with bacteria and laundry cycles showed statistically $(\mathrm{p}<0.05)$ significant differences in \% reduction of CFU. Percentage contributions on results were found to be $9 \%$ with concentration and $72.72 \%$ with laundry cycles. In case of chitosan for $15 \mathrm{~g} / \mathrm{L}$ finished cotton fabrics launderability results showed significant difference $(\mathrm{p}<0.05)$ for bacteria and laundering cycles on \% reduction in CFU with $91.8 \%$ contribution by laundering cycles. These results prove that laundering cycles had significant effect on antimicrobial activity for each agent.

\section{Physical properties of antimicrobial finished cotton}

Physical properties of finished cotton are summarized in Table 3. None of three antimicrobial agents showed any significant deterioration in tensile strength; $95 \%$ or more retention of tensile strength was reported for both warp and weft. Tear strength marked no change and rather slightly increased up to $10 \%$ for chitosan finished cotton due to jamming of yarns with its layer. Air permeability was decreased from 17.96 to around $16 \mathrm{~cm}^{3} / \mathrm{cm}^{2} / \mathrm{s}$ for both triclosan and silver finished fabrics both and $14.8 \mathrm{~cm}^{3} / \mathrm{cm}^{2} / \mathrm{s}$ for chitosan finished fabric due to blocking of the fabric pores with its layer. Total crease recovery angle (TCRA), stiffness, whiteness index of finished fabric remained almost unchanged for triclosan and silver based finishes but with chitosan decrease in whiteness index and increase in stiffness of fabric to a great extent from 2.3 to 2.88 for warp and from 1.52 to 1.94 for weft.

It was concluded that triclosan and silver based finishes did not alter the physical properties of cotton whereas chitosan affected the same and showed some negative impact on physical properties of finished cotton. With chitosan, stiffness increased to a great extent, air permeability decreased tremendously due to blocking of the fabric pore structure, TCRA decreased due to more add-on of finish on fabric, slight decrease in whiteness index but tear strength got increased compared to other finishes.

\section{Conclusions}

In this study three different types of antimicrobial agents were applied in pad-dry and pad-dry-cure technique and antimicrobial activity was evaluated against two bacteria i.e. S. aureus (Gram positive bacteria) and E. coli (Gram negative bacteria). Durability of finish and physical properties of finished cotton were also evaluated. For triclosan and

Table 3 Physical properties for antimicrobial finished cotton

\begin{tabular}{|c|c|c|c|c|c|c|c|c|c|c|c|}
\hline \multirow[t]{2}{*}{ S. no. } & \multirow[t]{2}{*}{$\begin{array}{l}\text { Antimicrobial } \\
\text { agent }\end{array}$} & \multirow[t]{2}{*}{$(g / L)$} & \multirow[t]{2}{*}{ TCRA } & \multicolumn{2}{|c|}{$\begin{array}{l}\text { Tensile } \\
\text { strength } \\
\text { (\% retention) }\end{array}$} & \multicolumn{2}{|c|}{$\begin{array}{l}\text { Tear strength } \\
\text { (\% retention) }\end{array}$} & \multicolumn{2}{|c|}{$\begin{array}{l}\text { Bending } \\
\text { length }(\mathrm{cm})\end{array}$} & \multirow[t]{2}{*}{ WI } & \multirow[t]{2}{*}{$\begin{array}{l}\mathrm{AP}\left(\mathrm{cm}^{3} /\right. \\
\left.\mathrm{cm}^{2} / \mathrm{s}\right)\end{array}$} \\
\hline & & & & Warp & Weft & Warp & Weft & Warp & Weft & & \\
\hline UN & - & - & 155 & 100 & 100 & 100 & 100 & 2.3 & 1.52 & 78.80 & 17.96 \\
\hline 1 & Triclosan & 20 & 153 & 95.38 & 97.24 & 104.27 & 104.39 & 2.11 & 1.47 & 78.05 & 16.45 \\
\hline 2 & Triclosan & 30 & 151 & 94.51 & 98.34 & 102.4 & 105.29 & 2.09 & 1.51 & 76.96 & 16.27 \\
\hline 3 & Silver & 30 & 149 & 98.53 & 97.9 & 106.6 & 103.8 & 2.16 & 1.5 & 77.11 & 16.26 \\
\hline 4 & Silver & 40 & 151 & 99.1 & 95.61 & 104.46 & 105.36 & 2.11 & 1.52 & 77.07 & 16.12 \\
\hline 5 & Chitosan & 15 & 142 & 98.8 & 97.89 & 110.89 & 112.73 & 2.88 & 1.78 & 74.82 & 14.58 \\
\hline
\end{tabular}

TCRA total crease recovery angle, WI Whiteness index, AP air permeability, UN untreated fabric 
silver based agents (leaching type), pad-dry application was most suitable but for chitosan, pad-dry-cure was found to be most effective. The best working $\mathrm{pH}$ was found to be 6 for triclosan and silver based finishes. Triclosan did not lose its activity at lower acidic $\mathrm{pH}$ whereas silver showed some loss of antimicrobial activity. All three antimicrobial agents showed overall good antimicrobial performances on finished cotton. Triclosan and silver based finishes showed remarkably more antimicrobial activity than that with chitosan finished cotton against $S$. aureus and E. coli at various concentrations. Chitosan was found to be more effective against Gram positive bacteria i.e. S. aureus. Finish durability results showed sustainability and excellent antimicrobial activity for triclosan and silver finished fabrics up to five laundering cycles but for chitosan percentage reduction rates in CFU were tremendously decreased by 5 th laundering cycle. Triclosan and silver caused no change in the physical properties of cotton except slight decrease in air permeability; chitosan adversely effected physical properties of finished cotton especially in handle of fabric i.e. stiffness and air permeability due to its layer formation on fabric.

\section{Authors' contributions}

Both the authors had planned the work. GD carried out the work and drafted the manuscript. Both authors read and approved the final manuscript.

\section{Acknowledgements}

Not required.

Compliance with ethical guidelines

Competing interests

The authors declare that they have no competing interests.

Received: 7 March 2015 Accepted: 4 August 2015

Published online: 27 August 2015

\section{References}

Annis, P. A. (2012). Understanding and improving the durability of textile. Cambridge: Woodhead publishing Ltd.

Bashar, M. M., \& Khan, M. A. (2013). An overview on surface modification of cotton fiber for apparel use. Journal of Polymers and the Environment, 21(1), 181-190. doi:10.1007/s10924-012-0476-8.

Budama, L., Çakır, B. A., Topel, Ö., \& Hoda, N. (2013). A new strategy for producing antibacterial textile surfaces using silver nanoparticles. Chemical Engineering Journal, 228, 489-495. doi:10.1016/j.cej.2013.05.018.

Dorugade, V. A., \& Bhagyashri, K. (2010). Antimicrobial finishing of textiles. Man-made textiles in India, 53(3), 89-95.

Dubas, S. T., Kumlangdudsana, P., \& Potiyaraj, P. (2006). Layer-by-layer deposition of antimicrobial silver. Colloids and Surfaces A: Physicochemical and Engineering Aspects, 289(1-3), 105-109. doi:10.1016/j.colsurfa.2006.04.012.

Elshafei, A., \& El-Zanfaly, H. T. (2011). Applications of the antimicrobial in the development of textiles. Asian Journal of Applied Sciences, 4(6), 585-595. doi:10.3923/aiaps.2011.585.595.

El-tahlawy, K.F., El-bendary, M.A., Elhendawy, A.G. \& Hudson, S.M. (2005). The antimicrobial activity of cotton fabrics treated with different crosslinking agents and chitosan. Carbohydrate Polymers, 60(4), 421-430.

Emam, H. E., Manian, P. A., Siroká, B., Duelli, H., Redl, B., Pipal, A., et al. (2013). Treatments to impart antimicrobial activity to clothing and household cellulosic-textiles-why "Nano"-silver? Journal of Cleaner Production, 39, 17-23. doi:10.1016/j.jclepro.2012.08.038

Gao, Y., \& Cranston, R. (2008). Recent advances in antimicrobial treatments of textiles. Textile Research Journal, 78(1), 60-72. doi:10.1177/0040517507082332.

Huang, K., Wu, W., Chen, J., \& Lian, H. (2008). Application of low-molecular-weight chitosan in durable press finishing. Carbohydrate Polymers, 73(2), 254-260. doi:10.1016/j.carbpol.2007.11.023.

Kut, D., Orhan, M., Günesoglu, C., \& Özakin, C. (2005). Effects of environmental conditions on the antibacterial activity of treated cotton knits. AATCC Review, 5(3), 25-28.

Mahapatra, N. N. (2013). Processing of silver fibre in textile industries. Colourage, 60(11), 98-100.

Mansfield, R. G. (2002). Keeping it fresh. Textile World, 152, 42-45.

Mao, J. (2002). Durable antimicrobal finish for cotton with new technology. AATCC Review, 2(12), 15-17.

Matyjas-Zgondek, E., Bacciarelli, A., Rybicki, E., Szynkowska, M. I., \& Kołodziejczyk, M. (2008). Antibacterial properties of silver-finished textiles. Fibres \& Textiles in Eastern Europe, 16(5), 101-107.

Mehmet, O. (2012). Determination and characterization of triclosan on polyethylene terephthalate fibers. Journal of Textiles \& Engineers, 19(85), 27-30. 
Montazer, M., Alimohammadi, F., Shamei, A., \& Rahimi, M. K. (2012). Durable antibacterial and cross-linking cotton with colloidal silver nanoparticles and butane tetracarboxylic acid without yellowing. Colloids and Surfaces B: Biointerfaces, 89, 196-201. doi:10.1016/j.colsurfb.2011.09.015.

Purvar, R., \& Joshi, M. (2004). Recent developments in antimicrobial finishing of textiles-a review. AATCC Review, 4(3), 22-26.

Raafat, D., Von Bargen, K., Haas, A., \& Sahl, H. (2008). Insights into the mode of action of chitosan as an antibacterial compound. Applied and Environmental Microbiology, 74(12), 3764-3773. doi:10.1128/AEM.00453-08.

Ramachandran, T., \& Rajendran, R. (2004). Antimicrobial textiles-An overview. IE (I) Journal TX, 84, $42-47$.

Ristić, T., Zemljič, L.F., Novak, M., Kunčič, M.K., Sonjak, S., Cimerman, N.G., et al. (2011). Antimicrobial efficiency of functionalized cellulose fibres as potential medical textiles. In A. Méndez-Vilas (Ed.), Science against microbial pathogens: communicating current research and technological advances (Vol. 1, pp. 36-51), Microbiology book series no. 3. Spain: Formatex Research Center.

Schindler, W. D., \& Hauser, P. J. (2004). Chemical finishing of textiles. Cambridge: Woodhead Publishing Limited.

Shrivastava, A., Koutu, B. B., \& Sharma, R. K. (2011). Anti-bacterial Rayon fibre. Man-Made Textiles in India, 39(3), $101-103$.

Srivastava, A. (2011). Anti-microbial finish on textiles. Colourage, 58(12), 33-35.

Swofford, H. W. (2010). An overview of antimicrobial testing for textile applications. AATCC Review, 10(6), 51-55.

Technical Data Sheet. (2000). Ultrafresh* NM-V2, Thomson Research Associates, E.P.A. Registration No. 10466-27.

Technical Data Sheet. (2013). N9 Pure Silver-Micro: Textile application guide. N9 World Technologies Pvt. Ltd, version (4).

Technical Bulletin (2004). Functional finishes for Cotton Products. North Carolina: Cotton Incorporated Technical Bulletin (ISP 1012, 1-8).

Thiry, M. C. (2010). Testing antimicrobial performance. AATCC Review, 10(6), 26-37.

Windler, L., Height, M., \& Nowack, B. (2013). Comparative evaluation of antimicrobials for textile applications. Environment International, 53, 62-73.

\section{Submit your manuscript to a SpringerOpen ${ }^{\circ}$ journal and benefit from:}

- Convenient online submission

- Rigorous peer review

- Immediate publication on acceptance

- Open access: articles freely available online

- High visibility within the field

- Retaining the copyright to your article

Submit your next manuscript at $>$ springeropen.com 